\title{
Research on the Causes and Coping Strategies of Financing Constraints of Small and Medium-Sized Cultural Enterprises
}

\author{
Weishuang $\mathrm{Xu}{ }^{1, \mathrm{a},}$ * \\ ${ }^{1}$ College of Economics and Management, Qilu Normal University, Jinan, Shandong, China \\ axwsjn@163.com
}

Keywords: Culture Industry; Financing Constraints; Causes; Coping Strategies

\begin{abstract}
The cultural industry has the characteristics of low carbon economy, high added value, reverse economic cycle and the whole industry chain. It has become an important choice for the pillar industry of national economic development. Consider the reality of our country, the cultural industry still faces many constraints, especially financial constraints if it intends to be the pillar industry of national economic development. Based on the analysis of the characteristics of small and medium-sized cultural enterprises, this paper focuses on the present situation and causes of small and medium-sized cultural enterprises financing. On the basis of which, this paper puts forward the coping strategies of solving financing constraint of small and medium-sized cultural enterprises from the view of cultural enterprises themselves, government, banks and supporting environment, so as to accelerate the development of Chinese culture industry and the integration of cultural industry and financial industry.
\end{abstract}

\section{Introduction}

The cultural industry has the characteristics of low carbon economy, high added value, reverse economic cycle and the whole industry chain. It has become an important choice for the pillar industry of national economic development (Yin Hongzhen, 2016)[1]. According to the estimation of National Bureau of Statistics (2017) [2], China's cultural industry added value accounted for $4.07 \%$ of GDP and the growth rate of cultural industry added value exceeding the same period GDP is $5.4 \%$ in 2016. Especially since 2012, the contribution of China's cultural industry to GDP growth reached an average of $6.0 \%$. This indicates that the cultural industry is playing an increasingly important role in promoting China's national economy to maintain high-speed development. However, consider the reality of our country, the cultural industry still faces many constraints, especially financial constraints if it intends to be the pillar industry of national economic development. Under the guidance of national cultural industry policy, the pattern of investment body diversification in China's cultural industry has gradually formed and the pace of social capital entering the cultural industry has also been accelerating. However, due to the special characteristics of cultural industry, the obstacle to effective docking between cultural industry and the financial industry is still not eliminated. The problem of financing constrains of cultural enterprises, especially small and medium-sized cultural enterprises have not yet been fundamentally solved. This has not only hindered the development of cultural industry itself, but also hindered the effective integration of cultural industry and financial industry. Based on this, it is very important significance to analyze the causes behind the financing constraints of cultural industry and put forward the corresponding coping strategies. This will accelerate the process of cultural industry development and the integration of cultural industry and financial industry. 


\section{Characteristics and Financing Status of Small and Medium-Sized Cultural Enterprises}

Characteristics of Small and Medium-Sized Cultural Enterprises. In China's cultural industry, 98.5\% of the enterprises belong to small and medium-sized enterprises. Small and medium-sized cultural enterprises have become the absolute subject of China's cultural industries. In addition to the common characteristics of cultural industries, small and medium-sized cultural enterprises also have their own special characteristics. (1) Intangible assets, mainly creative, knowledge and technology, are the core assets of enterprises. The characteristics of intangible assets determine that the development of cultural enterprises with high input, high recovery period, high risk and other characteristics, the development of cultural enterprises need a large amount of funds as a support. (2) The value of intangible assets and cultural products developed on the basis of intangible assets are highly uncertain. The characteristics of intangible assets, such as difficult to innovate, easy to replicate, difficult to evaluate and transfer, determine their own value have great uncertainty. The cultural products developed on the basis of intangible assets are mainly to meet people's spiritual needs. Its value not only depends on intangible assets itself, but also depends on the degree of consumer recognition. So the value of cultural products also has great uncertainty. (3) Most of the small and medium-sized cultural enterprises are in the start-up or growth period, the industrial chain is not perfect and has not formed a certain market scale and mature business model. Therefore, the ability of small and medium-sized cultural enterprises to cope with risks is relatively weak, and the risks are greater than those of large-sized cultural enterprises. (4) Most of the small and medium-sized cultural enterprises are in the front of the industrial chain and the product contents are mostly original. So the growth and development model of small and medium-sized cultural enterprises can not imitate the way or path of other enterprises. They must have their own out of the ordinary.

Financing Status of Small and Medium-Sized Cultural Enterprises. Under the guidance of national cultural industry policy, the diversification financing channels of cultural industries has gradually formed. Specifically, the financing channels of cultural industry mainly include the following aspects: internal funds of cultural enterprises, government financial funds, bank loans, direct financing of capital market, industrial investment funds and other private capital. But at the same time, the characteristics of cultural industry determines that its financing process is bound to face financial exclusion from all sides (Chen Xiaoming, Tian Feng, 2015)[3]. (1) The indirectly financing exclusion comes from banking industry. According to the information provided by “Chinese Banking Social Responsibility Report of 2014"[4], the cultural industry obtained a total of RMB 532.8 billion bank loans, accounting for only $0.6 \%$ of the total balance of bank loans and $5.4 \%$ of total new loans. Moreover, the loan of banking industry to cultural industry mainly flows to the major cultural industries projects, demonstration parks and key enterprises. The support of bank loans for small and medium-sized cultural enterprises with greater pressure to survive is relatively weak. (2) The direct financing exclusion come form capital market. According to the statistics, there were 189 listed cultural enterprises in China and 114 cultural enterprises listed in the new OTC market by the end of 2015. The capital market inflows into cultural industry was RMB 326 billion and only RMB 395 billion in 2016. However, these inflows have little relationship with small and medium-sized cultural enterprises. (3) The financial funds mainly flow to the state-owned cultural enterprises and cultural institutions. In 2016, the government invests in cultural industry RMB 717 million through the form of special industrial development funds, RMB 162 million through the form of cultural industry PPP demonstration project, RMB 13 billion through the form of special construction funds and invests in cultural business expenses RMB 77.069 billion. Therefore, under the above financing background, small and medium-sized cultural enterprises can 
only mainly rely on the internal funds of enterprises. The financing through other channels is not only limited in quantity, but also high in financing costs and risks. Zhu Jiaang (2017) [5] believes that the internal financing of small and medium-sized cultural enterprises in China accounts for about $80 \%$ of the total amount of financing, and only about $20 \%$ of the direct financing and indirect financing through the financial markets.

\section{The Causes of Financing Constraints Encountered by Small and Medium-Sized Cultural Enterprises}

The Financing Ability of Small and Medium-Sized Cultural Enterprises Outside Themselves is Relatively Weak. Financing difficulties of small and medium-sized enterprises is a long-standing problem. Lin Yifu (2001) [6] once pointed out that would bring an incentive agent problem because of the information asymmetry between the users and providers of funds, which will increase the difficulty of small and medium-sized enterprises financing. At the same time, due to the characteristics of small and medium-sized cultural enterprises mentioned above, it is difficult for small and medium-sized cultural enterprises to meet the financing conditions of the traditional financial system, and the basic conditions of direct financing from capital market. Therefore, the financing capacity of small and medium-sized cultural enterprises in general is relatively weak.

Government Supports the Development of Small and Medium-sized Cultural Enterprises is Insufficient. Government support the development of cultural industries is mainly reflected in the two aspects of policy support and capital investment, but these two aspects are not inclined to small and medium-sized cultural enterprises. (1) Policy aspect. Although the government has vigorously advocated the development of cultural industries, and introduced a number of policies to support from the aspects of special funds, tax preference, finance, operating environment and other aspects. However, these preferential policies are mainly based on macro planning and large-scale cultural enterprises group and rarely can be implemented on the small and medium-sized cultural enterprise. (2) Investment aspect. As mentioned earlier, the government financial funds mainly flow into the state-owned cultural enterprises and cultural institutions and flow into large-scale cultural industries projects and key cultural industries projects. Although the absolute amount of government investment in cultural industries increased year by year, the relative amount has not increased simultaneously. In 2016, the proportion of national cultural expenses accounted for $0.41 \%$ of total fiscal expenditure, but this proportion was consistently higher than $0.41 \%$ before 1999 and especially reached $0.52 \%$ in 1992 .

Banks Lack the Enthusiasm to Provide Financial Products for Small and Medium-Sized Cultural Enterprises. At present, the pricing mechanism, guarantee system and risk assessment system of bank financial products are mainly designed and developed according to the characteristics of traditional industries. The requirements for the guarantee system and risk assessment system have many obstacles to the cultural enterprises with light assets. It is difficult to form effective docking between the financial industry and culture industry's capital needs under the business model of mortgage-oriented. The banks will face the risks of shortage of professionals, information asymmetry, lack of effective guarantees and other aspects if they want to meet the financing needs of small and medium-sized cultural enterprises and design financial products according with the characteristics of cultural industry. Therefore, due to the nature of capital chasing profits and the requirements of risks avoiding, banks lack sufficient enthusiasm to innovate financial products for the cultural industries.

The Imperfect Supporting Mechanism has affected the Effective Docking Between the Funds Supply and Demand. The win-win situation can be achieved only the financing needs of 
small and medium-sized cultural enterprises form effective docking with the capital supply of capital suppliers. However, the imperfect supporting environment hinders the formation of such a win-win situation. (1) The related legal system lags behind and the legal environment is not perfect. The imperfect legal environment has affected the protection, evaluation and circulation of intangible assets mainly engaged in intellectual property rights, thus affected the convenience of cultural enterprises obtaining funds. (2) Poor communication of information. The information of funds demand of cultural enterprises and the information of funds supply provided by the investors can not be effectively docked. Even if the supply and demand of funds have been docked, they will not achieve the desired results due to asymmetric information. (3) Lack special intermediary services. The specialized intermediary service organizations, such as the intangible assets appraisal institution, the intangible assets mortgage, the guarantee and the circulation organization and the credit insurance organization are imperfect, which makes the fund supply and demand sides lack the effective communication platform.

\section{Coping strategies of small and medium-sized cultural enterprises in solving financing constraints}

Enhance the financing capacity of small and medium-sized cultural enterprises themselves. The enhancement of self-financing ability of small and medium-sized cultural enterprises is the key to expand financing channels. (1) Small and medium-sized cultural enterprises should strengthen their own transformation development and design a large number of cultural products to meet the needs of consumers. Thereby enhance the market competitiveness of cultural products. (2) Enhance the connotation of their own intangible assets to make light assets are not "light". On the basis of enhancing the connotation of their own intangible assets, cultural enterprises can make their own social recognition degree greatly improved with the improvement of external financing environment. (3) Small and medium-sized cultural enterprises will become bigger and stronger through the way of enterprise cooperation and even merger, thus they will become a key chain of cultural industry chain. On this basis, the efficiency of the existing funds will be raised.

Increase the support of government. The government's support for cultural industry is mainly reflected in creating a good business environment. (1) Increase policy support and carry out institutional innovations. These will guide more investment flow into the cultural industry through the innovation of cultural system mechanisms, the introduction of more conducive policy measures to the development of cultural industries and reducing capital market access threshold. (2) Give full play the guidance and leverage function of government financial funds. The government's financial funds should mainly play a guiding and leverage role and guide other channels funds flow into cultural industry to make up for the financing gap of cultural enterprises. Such as in 2016, PPP cultural industry demonstration projects funds RMB 162 million attracts other parties investment reach RMB 35.8 billion, special construction funds RMB 13 billion is expected to pull about RMB 100 billion social cultural tourism investment.

Banks accelerate the innovation of financial products for cultural industries. Cultural and financial cooperation is an important driving force for the sustained development of China's cultural industry. (1) The banking industry should change the service concept, speed up the pace of financial product innovation and develop more financial products aimed at the characteristics of the cultural industry. Such as the measures of introduction intangible assets pledged credit products, the reduction of financing threshold of copyright and patent and other measures to accelerate the integration of financial and cultural industries. (2) The banking industry should do a good job of market segmentation. According to the characteristics of their own assets allocation, the banking 
industry should look for the appropriate entry field and credit direction and promote the development of cultural industry more targeted.

Improve the supporting mechanism of cultural industry financing and consolidate the foundation of financial industry to support the development of cultural industries. The main aim of perfecting the supporting mechanism of cultural industry financing is to let the market solve the problem of financing docking between the cultural industry and the financial industry by giving full play the function of market resource allocation. (1) Set up investment and financing information service platform for small and medium-sized cultural enterprises. The construction of investment and financing information service platform can reduce the degree of information asymmetry between investments and financing, reduce the cost of information search and provide high quality information service for financial institutions, large enterprises and social funds to enter the cultural industry. As from 2015, Department of Culture Industry of Ministry of Culture joint Shenzhen Stock Exchange launched a small and medium-sized cultural enterprises investment and financing project road show activities. This activities set up an effective information exchange platform for cultural enterprise capital supply and demand. (2) Establish a special intangible assets valuation and trading platform so as to promote the pricing and circulation of intangible assets. (3) Establish a sound risk sharing and compensation mechanism. Such as the establishment of cultural industry policy guarantees and insurance institutions, the establishment of cultural and creative industries risk compensation fund, so as to reduce the financing risks of small and medium-sized cultural enterprises and solve financial industry's worries.

\section{Acknowledgements}

This paper is the stage research results of Shandong Province Art Science Key Project of 2017 (Project number: 201706340).

\section{Reference}

[1] Yin Hongzhen. Financing Dilemma of Western Cultural Industry and Its Solution [J]. Social Sciences in Guangxi, 2016(05).

[2] http://www.stats.gov.cn/tjsj/sjjd/201707/t20170727_1517428.html

[3] Chen Xiaoming, Tian Feng. Finance Exclusion, Integration of Industry and Finance and Innovation of Cultural Industry Financing Mechanism [J]. Academic Forum, 2015(03).

[4] http://www.china-cba.net/bencandy.php?fid=43\&id=14192

[5] Zhu Jiaang. Difficulties and Countermeasures of Finance Docking Cultural Industry [J]. Modern Management Science, 2017(05).

[6] Lin Yifu. Development of Small and Medium-sized Financial Institutions and Financing of Small and Medium-sized Enterprises [J]. Economic Research Journal, 2001(01). 